\title{
KEIKUTSERTAAN DALAM MAJELIS TAKLIM DAN PENGAMALAN KEAGAMAAN IBU RUMAH TANGGA
}

Oleh:

\section{Sahadir Nasution ${ }^{1}$}

\begin{abstract}
Majelis taklim merupakan lembaga pendidikan masyarakat yang tumbuh dan berkembang dari kalangan masyarakat Islam itu sendiri yang kepentingannya untuk kemaslahatan umat manusia. Bila dilihat dari struktur organisasinya, majelis taklim termasuk organisasi pendidikan luar sekolah (nonformal) yang bercirikan khusus keagamaan Islam. Bila dilihat dari segi tujuan, majelis taklim adalah termasuk lembaga atau sarana dakwah islamiah yang secara self-standingdan self-disciplined dapat mengatur dan melaksanakan kegiatan-kegiatannya. Didalamnya berkembang prinsip demokrasi yang berdasarkan musyawarah untuk mufakat demi kelancaran pelaksanaan al-taklim al-Islamy sesuai dengan tuntutan pesertanya.

Pengamalan keagamaan adalah perbuatan yang dilakukan seorang hamba sebagai bentuk ikatan/kepatuhan kepada Allah SWT dalam rangka mendekatkan diri, dengan taat dan patuh melaksanakan perintah dan anjuran-Nya serta menjauhi segala larangan-Nya. Pengamalan keagamaan yang dimaksud di sini adalah melaksanakan ajaran agama dalam kehidupan sehari-hari, khususnya dalam aspek akidah, ibadah dan akhlak
\end{abstract}

Keywords: Majelis taklim, pendidikan nonformal, pengamalan keagamaan

\section{Pendahuluan}

Majelis taklim merupakan salah satu lembaga pendidikan Islam yang bersifat nonformal, yang senantiasa menanamkan akhlak yang luhur dan mulia, meningkatkan kemajuan ilmu pengetahuan dan ketrampilan jemaahnya serta memberantas kebodohan umat Islam agar memperoleh kehidupanyang bahagia dan sejahtera dan diridoi oleh Allah SWT.

${ }^{1}$ Penulis adalah Dosen Fakultas Tarbiyah dan Ilmu Keguruan IAIN Padangsidimpuan 
Majelis taklim merupakan lembaga pendidikan masyarakat yang tumbuh dan berkembang dari kalangan masyarakat Islam itu sendiri yang kepentingannya untuk kemaslahatan umat manusia. ${ }^{2}$

Bila dilihat dari struktur organisasinya, majelis taklim termasuk organisasi pendidikan luar sekolah (nonformal) yang bercirikan khusus keagamaan Islam. Bila dilihat dari segi tujuan, majelis taklim adalah termasuk lembaga atau sarana dakwah islamiah yang secara self-standingdan self-disciplined dapat mengatur dan melaksanakan kegiatan-kegiatannya. Didalamnya berkembang prinsip demokrasi yang berdasarkan musyawarah untuk mufakat demi kelancaran pelaksanaan altaklim al-Islamy sesuai dengan tuntutan pesertanya. ${ }^{3}$

Majelis taklim sebagai salah satu bentuk pendidikan Islam nonformal, mempunyai andil besar dalam rangka membina pengetahuan keislaman masyarakat khususnya bagi masyarakat yang tidak sempat mengenyam pendidikan Islam yang formal. Peserta pengajian majelis taklim tidak dibatasi tingkat usia, kemampuan atau lainnya tapi siapa saja yang berminat boleh mengikutinya. ${ }^{4}$ Sebab menuntut ilmu adalah kewajiban setiap muslim, sebagaimana dalam sebuah Hadis Nabi Muhammad SAW yang berbunyi:

طلب العلم فريضة على كل مسلم وان طالب العلم يستغفرله كل شئ حتى الحيتان فى البحر ( رو اه ابن عبد البحر عن انس)

Artinya: Menuntut ilmu adalah fardu atas tiap-tiap orang Islam, dan sesungguhnya orang yang menuntut ilmu itu meminta ampun baginya tiap-tiap sesuatu sehingga ikan-ikan dalam lautan (pun meminta ampun untuknya). (Hadis Riwayat Ibn Abdulbarr dari Anas). ${ }^{5}$

Menuntut ilmu tidak ada batasnya, sebagaimana dalam sebuah Hadis Nabi Muhammad SAW yang berbunyi:

$$
\text { اطلب العلم من المهد الى اللحد (رو اه احمد) }
$$

${ }^{2}$ Enung K Rukiati dan Fenti Hikmawati, Sejarah Pendidikan Islam Di Indonesia (Bandung: Pustaka Setia, 2006), hlm. 131.

${ }^{3}$ Muzayyin Arifin, Kapita Selekta Pendidikan Islam (Jakarta: PT Bumi Aksara, 2003), hlm. 80.

${ }^{4}$ Kustini, Peningkatan Peran Serta Masyarakat Dalam Pendalaman Ajaran Agama Melalui Majelis Taklim (Jakarta: Puslitbang Kehidupan Keagamaan, 2007), hlm. 21.

${ }^{5} \mathrm{Ahmad}$ Al-Hasyim, Mukhtarul Ahadis, (Indonesia: Al-Haramain Jaya, 2005), hlm. 54. 
Artinya: Tuntutlah ilmu pengetahuan dari buaian hingga liang lahat. (HR. Ahmad). ${ }^{6}$

Dari hadis di atas dapat dilihat bahwa batas menuntut ilmu tidak ada atau berlangsung seumur hidup.Dan orang yang mencari ilmu pengetahuan sangat besar pahalanya, sehingga ikan-ikan di laut turut mendo'akan, meminta ampun kepada Allah SWT untuknya, dan seluruh isi dunia turut memohonkan ampunan untuknya.

\section{Keikutsertaan dalam Majelis Taklim}

\section{Pengertian Keikusertaan}

Dalam Kamus Besar Bahasa Indonesia keikutsertaan berasal dari kata ikut yaitu menyertai orang bepergian (berjalan, bekerja dsb), turut, serta.Keikutsertaan adalah tindakan ikut serta dalam kegiatan tersebut. ${ }^{7}$

\section{Pengertian Majelis Taklim}

Dalam Kamus Besar Bahasa Indonesia, "Majelis Taklim" mengandung dua unsur kata, yaitu "Majelis" dan "Taklim". Majelis dapat diartikan: "pertemuan (perkumpulan) orang banyak, sedangkan Taklim adalah lembaga (organisasi) sebagai wadah pengajian". 8

Dari segi etimologis, perkataan majelis taklim berasal dari bahasa Arab, yang terdiri dari dua kata yaitu majelis dan taklim.Majelis artinya tempat duduk, tempat sidang, dewan.Dengan demikian secara bahasa majelis taklim adalah tempat duduk melaksanakan pengajaran atau pengajian agama Islam. ${ }^{9}$

Dari pengertian di atas dapat dipahami bahwa majelis taklim adalah suatu wadah organisasi sebagai tempat perkumpulan orang banyak dalam rangka mengikuti pengajaran agama Islam. Dimana para jama'ahnya ada dari kalangan ibu-ibu dan juga bapak-bapak baik yang masih muda maupun yang sudah lanjut usia. Majelis taklim juga merupakan wahana para da'i atau ustadz untuk menyampaikan berbagai pengajaran agama Islam sesuai dengan kebutuhan para jama'ahnya.

Dalam kaitannya pemahaman di atas dapat dilihat dalam ensiklopedi Islam, pada musyawarah majelis ta'lim se-DKI Jakarta (9-10 juli 1980) yang

${ }^{6} \mathrm{Ibid}, \mathrm{hlm} .58$

${ }^{7}$ Tim Penyusun Kamus Departemen Pendidikan dan Kebudayaan, Kamus Besar Bahasa Indonesia, (Jakarta: Balai Pustaka, 2001), hlm. 422.

${ }^{8}$ Ibid., hlm. 699.

${ }^{9}$ Hasbullah, Kapita Selekta Pendidikan Islam (Jakarta: PT Raja Grafindo Persada, 1996), hlm. 95 
memberikan batasan yang lebih defenitif tentang majelis ta'lim: yaitu suatu lembaga pendidikan non formal Islam yang memiliki kurikulum tersendiri, diselenggarakan secara berkala dan teratur dan diikuti oleh jama'ah yang relatif banyak, bertujuan untuk membina dan membangun hubungan yang santun dan serasi antara manusia dengan sesamanya, serta antara manusia dengan Allah SWT, antara manusia dengan sesamanya, serta antara manusia dengan lingkungannya, dalam rangka membina masyarakat yang bertakwa kepada Allah SWT. ${ }^{10}$

Berdasarkan pengertian diatas keberadaan majelis ta'lim memiliki peran yang sangat penting dalam laju perkembangan masyarakat, selain majelis taklim itu sebagai wadah atau tempat mendapatkan ilmu pengetahuan agama, majelis taklim juga sebagai tempat mendekatkan diri kepada Allah SWT melalui hubungan yang santun dengan sesame manusia dan juga lingkungan sekitar. Dengan demikian majelis taklim merupakan salah satu sarana yang efektif dalam penyampaian pesan-pesan keagamaan. Pada majelis taklim terdapat hal-hal yang cukup membedakan dengan yang lain, diantaranya:

a. Majelis taklim adalah lembaga pendidikan nonformal Islam.

b. Waktu belajarnya berkala tapi teratur, tidak setiap hari sebagaimana halnya sekolah atau madrasah.

c. Pengikut atau pesertanya disebut jema'ah (orang banyak), bukan pelajar atau santri. Hal ini didasarkan kepada kehadiran di majelis taklim bukan merupakan kewajiban sebagaimana dengan kewajiban murid menghadiri sekolah atau madrasah.

d. Tujuannya yaitu memasyarakatkan ajaran Islam.

\section{Fungsi dan Tujuan Majelis Taklim}

Sebagai lembaga pendidikan non formal, majelis taklim berfungsi sebagai berikut:

a. Membina dan mengembangkan ajaran Islam dalam rangka membentuk masyarakat yang bertakwa kepada Allah SWT.

b. Sebagai taman rekreasi rohaniah, karena penyelenggarannya bersifat santai.

c. Sebagai ajang berlangsungnya silaturrahmi masal yang dapat menghidup suburkan dakwah dan ukhuwah Islamiyah.

d. Sebagai sarana dialog berkesinambungan antara ulama dan umara dengan umat.

\footnotetext{
${ }^{10}$ Dewan Redaksi, Ensiklopedi Islam Jilid III, (Jakarta: Ikthiar Baru Van Hoeve, 2001), hlm.
} 
e. Sebagai media penyampaian gagasan yang bermanfaat bagi pembangunan umat bangsa pada umumnya. ${ }^{11}$

Sementara fungsi lain sebagaimana yang dijelaskan Helmawati bahwa majelis taklim sebagai lembaga pendidikan nonformal memilki beberapa fungsi, diantaranya:

a. Fungsi keagamaan, yakni membina dan mengembangkan ajaran Islam dalam rangka membentuk masyarakat yang beriman dan bertakwa kepada Allah SWT.

b. Fungsi pendidikan, yakni menjadi pusat kegiatan belajar masyarakat (learning society), ketrampilan hidup, dan kewirausahaan.

c. Fungsi sosial, yakni menjadi wahana silaturrahim, menyampaikan gagasan, dan sekaligus sarana dialog antara ulama, umara, dan umat.

d. Fungsi ekonomi, yakni sebagai sarana tempat pembinaan dan pemberdayaan ekonomi jama'ahnya.

e. Fungsi ketahanan bangsa, yakni menjadi wahana pencerahan umat dalam kehidupan beragama, bermasyarakat, dan berbangsa. ${ }^{12}$

Oleh karena sembahan dan ibadah hanya untuk Allah SWT, maka Allah mengajarkan tata cara tersebut melalui sang rasul yaitu Nabi Muhammad SAW kepada manusia agar tercapai sembahan dan ibadah yang Allah inginkan, maka dari itu alangkah pentingnya bagi manusia untuk mengetahui hal agama tentunya hanya dengan belajar. Belajar atau pendidikan yang tertuang dalam hadis diatas mempunyai tujuan sesuai dengan tujuan pendidikan yang diharapkan oleh Omar Muhammad Al-Toumy Al-Syaibani, mencakup beberapa perubahan yang diinginkan dalam tiga aspek, yaitu: ${ }^{13}$

a. Tujuan Individual yang berkaitan dengan individu, pelajaran dengan pribadipribadi mereka. Perubahan yang diharapkan meliputi: tingkah laku, aktivitas dan pencapaiannya, pertumbuhan pribadi mereka serta persiapan untuk kehidupan di dunia dan akhirat.

b. Tujuan Sosial yang berkaitan dengan kehidupan masyarakat, baik tingkah laku masyarakat pada umumnya, maupun pertumbuhan, memperkaya pengalaman dan kemajuan-kemajuan yang diinginkan.

\footnotetext{
${ }^{11}$ Hasbullah, Op.Cit, hlm. 101.

${ }^{12}$ Helmawati, Pendidikan Nasional dan Optimalisasi Majelis Taklim: Peran Aktif Majelis Taklim Meningkatkan Mutu Pendidikan (Jakarta: Rineka Cipta, 2013), hlm. 91.

${ }^{13} \mathrm{M}$. Ridlwan Nasir, Mencari Tipologi Format Pendidikan Ideal, (Yogyakarta: Pustaka Pelajar, 2005), hlm. 63.
} 
c. Tujuan Profesional yang berkaitan dengan pendidikan dan pengajaran sebagai ilmu, seni profesi dan sebagai suatu aktivitas diantara aktivitasaktivitas masyarakat.

Selanjutnya dalam proses mempelajari agama Islam banyak cara yang dilakukan, salah satunya dengan mengadakan majelis taklim. Karena dengan mengikuti majelis taklim tersebut sedikit banyaknya akan menambah pengetahuan tentang agama Islam khususnya yang berkaitan dengan ibadah.

Dari ulasan di atas dapat diambil kesimpulan bahwa majelis taklim itu dapat memberikan dampak yang positif bagi masyarakat dalam peningkatan pengetahuan agama bagi setiap anggota majelis taklim secara individual.

\section{Klasifikasi dan Metode Majelis Taklim}

Majelis taklim dapat diklasifikasikan kepada dua bagian utama, yaitu:

a. Majelis taklim yang pesertanya terbagi dari jenis tertentu, seperti kaum bapak, ibu, remaja, anak-anak dan campuran (tua, muda, pria dan wanita).

b. Majelis taklim yang diselenggarakan oleh lembaga-lembaga sosial keagamaan, kelompok penduduk di suatu daerah, instansi dan organisasi tertentu.

Sedangkan metode-metode yang digunakan dalam pengajian majelis taklim adalah sebagai berikut:

a. Metode ceramah, terdiri dari ceramah umum yaitu ustadz yang bertindak aktif memberikan pengajaran sementara jama'ah pasif, dan ceramah khusus yaitu pengejaran dan jama'ahnya sama-sama aktif dalam berdiskusi.

b. Metode halaqoh, yaitu pengajaran membaca kitab tertentu sementara jama'ah mendengarkan.

c. Metode campuran, yaitu melaksanakan berbagai metode sesuai dengan kebutuhan. ${ }^{14}$

Untuk menyampaikan pembelajaran kepada para jama'ah agar tercapainya tujuan pembelajaran, disini diperlukan bukan hanya metodemetode pembelajaran tetapi diperlukan juga sistem pendidikan yang integralistik. Dimana bagi para pemimpin pengajian, da'i, atau mubalig dalam proses penyajian materi agama kepada para peserta perlu berwawasan yang didasarkan atas sistem pendekatan antara lain: ${ }^{15}$

a. Pendekatan psikologis yang menuntut kepada pemahaman terhadap kecenderungan dan tingkat kemampuan pemahaman peserta didik untuk

${ }^{14}$ Ibid., hlm. 122.

${ }^{15}$ Muzayyin Arifin, Kapita Selekta Pendidikan Islam (Jakarta: Bumi Aksara, 2003), hlm. 8385. 
menyerap materi penyajian. Untuk itu, diatur pengelolaan kelompok pengajian berdasarkan usia dan profesi peserta didik yang homogen. Nabi memerintahkan agar kita berbicara kepada audiens berdasarkan atas kemampuan berpikir mereka.

b. Pendekatan sosiokultural menghendaki agar kita dapat membawa suasana kejiwaan peserta didik/pengajian kearah sikap komunikatif dan interaktif dengan lingkungan sosiokultural yang positif di sekitarnya. Sehingga tidak menimbulkan ketegangan atau benturan dengan realitas lingkungannya. Para wali Sembilan dahulu bersikap bersahabat dan akrab dengan lingkungan sosiokultural (di jawa) dalam dakwah-dakwah mereka, sehingga tidak timbul benturan sosiokultural dengan unsur- unsur tradisional yang telah mapan dalam masyarakat. Namun, secara bijaksana dan bertahap lingkungan sosiokultural dapat diubah sesuai tuntutan agama. Dalam hal ini, perlu diamalkan firman Allah bahwa para da'i wajib mengajak kepada jalan Allah dengan bijaksana dan tutur kata yang baik dan bermujadalah dengan cara yang paling baik.

c. Pendekatan religius menuntut kepada kita untuk mampu menguak dan menginterpretasikan ajaran agama yang menimbulkan jiwa katarsis dalam tiap pribadi peserta didik. Perlu kita pahamkan kembali perintah Allah SWT. antara lain mengajak kita untuk selalu berzikir kepada Allah SWT, seperti firman-Nya:

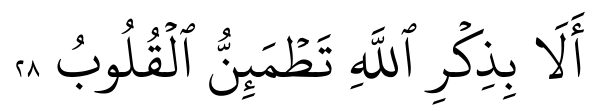

Artinya: Ingatlah bahwa dengan berzikir kepada Allah, hati menjadi tentram. (QS. Ar-Ra'd: 28)

d. Pendekatan saintifik menuntut kita untuk mampu menganalisis dan menafsirkan ayat-ayat ataupun al-Hadis yang relevan dengan tuntutan perkembangan ilmu pengetahuan. Seperti himbauan Allah SWT. tentang penyelidikan terhadap segala ciptaan Allah SWT. di jagat raya atau tantangan Allah SWT. kepada manusia dan jin menjelejahi ruang angkasa luar yang tanpa batas itu sesuai firman-Nya:

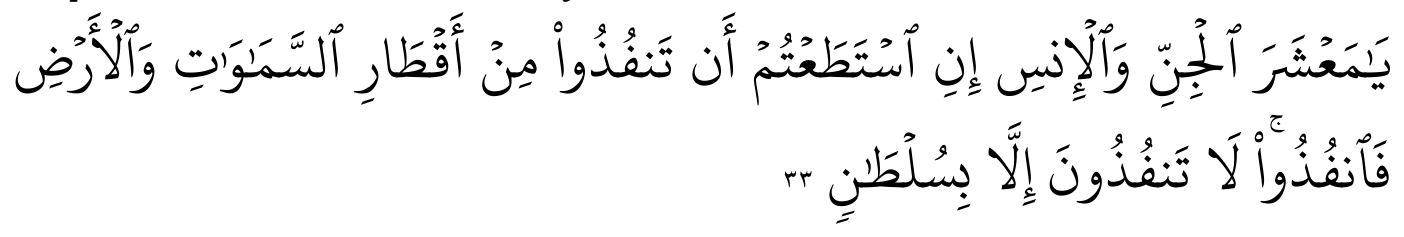

Artinya: "Wahai jin dan manusia jika kamu sekalian mampu untuk menembus menjelajahi langit dan bumi, tembuslah: namun 
kamu tidak akan mampu menembusnya kecuali dengan kekuatan (ilmu dan teknologi). (QS. Ar-Rahman: 33)

e. Pendekatan pembangunan menuntut kita untuk menggali sumber motivasi dari dalam ajaran agama yang dapat memberikan gairah dan semangat membangun. Posisi dan fungsi umat Islam manusia ciptaan Allah adalah menjadi khalifah di muka bumi yang harus menggali, mengolah, dan memanfaatkan kekayaan bagi kepentingan kesejahteraan hidupnya. Sesuai firman-Nya:

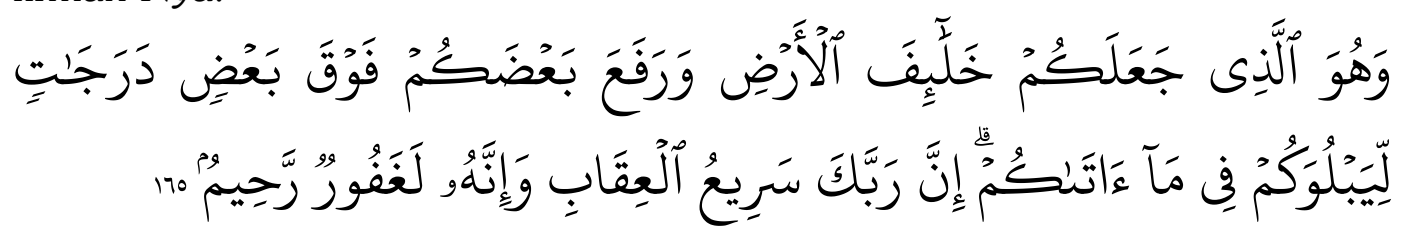

Artinya: "Dan Dia lah yang menjadikan kamu penguasa-penguasa di bumi dan Dia meninggikan sebahagian kamu atas sebahagian (yang lain) beberapa derajat, untuk mengujimu tentang apa yang diberikan-Nya kepadamu. Sesungguhnya Tuhanmu Amat cepat siksaan-Nya dan Sesungguhnya Dia Maha Pengampun lagi Maha Penyayang".(Al-An'am 165)

f. Pendekatan security (keamanan) dan prosperity(kemakmuran) mengharuskan kita untuk mengamalkan ajaran agama dari sudut kemanfaatan untuk hidup rukun, bersatu padu sebagai satu bangsa, satu tanah air yang berketahanan mental dan nasional, berwawasan bangsa (wawasan nusantara) cinta kepada pola hidup sederhana, produktif, dan mandiri. Dalam Islam banyak kita temukan ajaran yang mengajak kepada sikap demikian, antara lain ajakan kepada hidup berukhuwah Islamiah, berlomba dalam kebajikan, berta'aruf antara suku-suku, bekerja keras untuk dunianya dan sebagainya. Sebagimana firman Allah SWT. sebagai berikut:

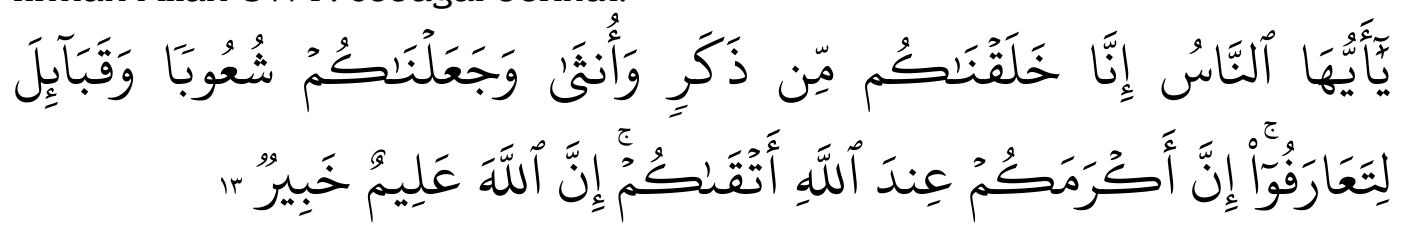

Artinya: "Hai manusia, Sesungguhnya Kami menciptakan kamu dari seorang laki-laki dan seorang perempuan dan menjadikan kamu berbangsa -bangsa dan bersuku-suku supaya kamu saling kenalmengenal. Sesungguhnya orang yang paling mulia diantara 
kamu disisi Allah ialah orang yang paling taqwa diantara kamu.Sesungguhnya Allah Maha mengetahui lagi Maha Mengenal”.(Al-Hujrat: 13)

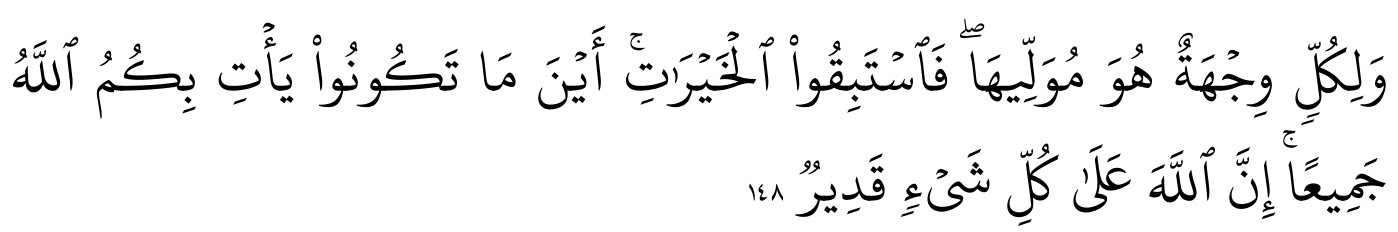

Artinya: "dan bagi tiap-tiap umat ada kiblatnya (sendiri) yang ia menghadap kepadanya. Maka berlomba-lombalah (dalam membuat) kebaikan.di mana saja kamu berada pasti Allah akan mengumpulkan kamu sekalian (pada hari kiamat). Sesungguhnya Allah Maha Kuasa atas segala sesuatu". (AlBaqarah 148)

Dengan pendekatan-pendekatan tersebut diharapkan bisa memudahkan bagi para mubalig dalam menyampaikan ajaran Islam sehingga majelis taklim tersebut bisa berfungsi secara efektif dan efisien.

\section{Kurikulum Majelis Taklim}

Kata kurikulum berasal dari bahasa Yunani yang semula digunakan dalam bidang olahraga, yaitu curere yang berarti jarak tempuh lari, yakni jarak yang harus ditempuh dalam kegiatan berlari mulai dari start hingga finish.Pengertian ini kemudian diterapkan dalam bidang pendidikan.Dalam bahasa Arab, istilah "kurikulum" diartikan dengan Manhaj,yakni jalan yang terang, atau jalan terang yang dilalui oleh manusia pada bidang kehidupannya.Dalam konteks pendidikan, kurikulum berarti jalan terang yang dilalui oleh pendidik/guru dengan peserta didik untuk mengembangkan pengetahuan, keterampilan dan sikap serta nilai-nilai. ${ }^{16}$

Menurut Mukhtar kurikulum merupakan seperangkat rencana dan pengaturan mengenai isi dan bahan pelajaran, serta cara yang digunakan sebagai pedoman penyelenggaraan kegiatan pembelajaran. Kurikulum berfungsi sebagai wahana untuk mewujudkan tujuan pendidikan pada masing-masing

${ }^{16}$ Muhaimin, Pengembangan Kurikulum Pendidikan Agama Islam Di Sekolah, Madrasah, Dan Perguruan Tinggi (Jakarta: RajaGrafindo Persada, 2009), hlm. 1. 
jenis/jenjang/satuan pendidikan yang pada gilirannya merupakan pencapaian tujuan pendidikan nasional. ${ }^{17}$

Sebuah kurikulum yang baik merupakan rencana dan pengaturan pembelajaran yang mencakup:

a. Tujuan pembelajaran;

b. Isi (mata pelajaran);

c. Jadwal pembelajaran;

d. Bahan (sumber pembelajaran);

e. Strategi dan metode belajar mengajar; dan

f. Sistem evaluasi pembelajaran. ${ }^{18}$

Kurikulum majelis taklim berisi ajaran Islam dengan segala aspeknya. Oleh karena itu, bahan atau materi pengajarannya berupa: tafsir, hadis, fiqh, tasawuf, tarikh Islam, bahasa Arab, ataupun masalah-masalh kehidupan yang ditinjau dari aspek ajaran Islam. ${ }^{19}$

Helmawati mengatakan dalam bukunya "pendidikan Nasional dan optimalisasi majelis taklim", mengingat majelis taklim memiliki keterbatasan waktu, tenaga pengajar, serta keterbatasan pemahaman keagamaan para jama'ah, maka majelis taklim tidak perlu mengambil materi-materi tersebut secara keseluruhan. Majelis taklim dapat saja mengambil beberapa materi atau bahan pengajaran berdasarkan skala prioritas dan sesuai dengan tingkat pemahaman para jama'ahnya. ${ }^{20}$

Kurikulum dalam kajian di majelis taklim ada yang masih menggunakan kitab (klasik) dengan bahasa Arab, ada juga yang menggunakan materi-materi dari kitab pengetahuan umum yang modern.Selain itu penyusunan kurikulum ada yang telah terstruktur dan ada yang belum terstruktur.

Kurikulum yang terstruktur adalah program kurikulum yang mengikuti program yang telah ditetapkan atau disusun oleh pemerintah atau juga pengelola majelis taklim.Sedangkan kurikulum tidak terstruktur adalah program kajian yang tidak ditetapkan atau disusun dahulu. Materi yang akandiberikan pada jama'ah tergantung pemateri atau ustadz yang ditunjuk pengelola. ${ }^{21}$

\section{Kegiatan Majelis Taklim}

${ }^{17}$ Mukhtar, Desain Pembelajaran Pendidikan Agama Islam (Jakarta: Misaka Galiza, 2003), hlm. 30 .

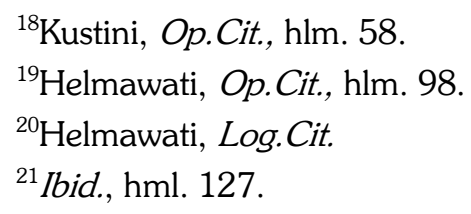


Sebagai salah satu lembaga pendidikan nonformal, pelaksanaan atau kegiatan di majelis taklim tidak terikat oleh waktu.Kegiatan di majelis taklim dapat dihadiri di pagi hari, siang, sore, atau malam hari sesuai dengan ketersediaan waktu jemaah yang bersangkutan.

Jika dilihat kegiatan-kegiatan majelis taklim ada yang sifatnya dilakukan secara rutin yaitu melaksanakan pengajian, sedangkan yang sifatnya musiman adalah peringatan hari-hari besar agama Islam dan bentuk kegiatan sosial lainnya.

Adapun kegiatan-kegiatan yang dilaksanakan dalam majelis taklim adalah:

a. Pengajian rutin.

Bila dilihat kegiatan yang pertama adalah melakukan pengajaran rutin.Hal ini dilakukan berdasarkan kesepakatan antara guru dengan jama'ah tentang pelaksanaannya dilakukan satu kali seminggu atau lebih.Pengajian tersebut dilakukan secara terus menerus sesuai dengan waktu yang disepakati bersama.

b. Melakukan kegiatan peringatan hari-hari besar Islam.

Sedangkan kegiatan memperingati hari-hari besar agama Islam, seperti peringatan maulid Nabi Muhammad SAW., peringatan Isra' Mi'raj Nabi Muhammad SAW., penyambutan bulan suci Ramadhan, dan lain-lain.

c. Kegiatan sosial lainnya.

Dalam bidang social dapat dilakukan berupa kebersihan lingkungan, rumah ibadah, memberikan bantuan baik berupa materi maupun moril kepada anggota majelis yang ditimpa musibah, dan lain sebaginya. ${ }^{22}$

\section{Manfaat Majelis Taklim}

Seperti yang telah kita ketahui bahwa majelis taklim itu adalah sebagai tempat untuk melaksanakan pengajaran agama Islam, tentu mengandung manfaat bagi para jema'ahnya, begitu juga kepada guru yang melaksanakan pengajaran tersebut.

Jika dilihat dari Manfaat majelis taklim tersebut secara garis besarnya ada empat macam, yaitu:

a. Sebagai wadah untuk membina dan mengembangkan kehidupan beragama dalam rangka membentuk masyarakat yang bertaqwa kepada Allah SWT.

b. Taman rekreasi rohaniyah

c. Wadah silaturahmi yang menghidupkan syiar Islam

${ }^{22}$ Dewan Redaksi, Op.Cit., hlm. 121. 
d. Media menyampaikan gagasan yang bermanfaat bagi pembangunan umat dan bangsa.

Bila dilihat manfaat majelis taklim di atas dapat dipahami bahwa yang pertama sekali adalah untuk mebina dan mengembangkan kehidupan beragama dalam rangka membentuk masyarakat yang bertaqwa kepada Allah SWT. Hal ini disebabkan majelis taklim tersebut dilaksanakan pengajaran agama Islam, baik dalam bentuk ceramah, tanya jawab, praktek, dan lain sebagainya.

Selanjutnya manfaat kedua dari majelis taklim tersebut adalah sebagai taman rekreasi rohaniah. Maksudnya adalah sebagai tempat yang baik untuk menumbuh suburkan kehidupan rohaniah, sebab di dalam taman tersebut (majelis taklim) diberikan berbagai petunjuk keagamaan (ilmu pengetahuan agama) untuk diamalkan sehingga memperoleh keselamatan di dunia dan akhirat.

Untuk itu bila rohani manusia diisi dengan ilmu pengetahuan akan dapat memberikan ketenangan jiwa, karena dalam tingkah lakunya sesuai dengan tuntutan ajaran Islam. Maka dari itu majelis taklim yang merupakan salah satu tempat rekreasi bagi rohaniyah.

Manfaat yang terakhir adalah sebagai media penyampaian gagasan yang bermanfaan bagi pembangunan umat dan bangsa.Hal ini tentu ditujukan kepada seorang da'I atau guru agama Islam yang diberi tugas untuk menyampaikan syari'at Islam kepada manusia sehingga dapat mengamalkannya. Untuk itu manfaat majelis taklim bukan saja berguna bagi para jamaahnya akan tetapi juga pembangunan bangsa dan Negara.

\section{Materi Majelis Taklim}

Majelis Taklim merupakan salah satu sarana pendidikan agama Islam. Oleh karena itu materi yang disajikan dalam majelis taklim sama dengan materi yang disajikan dalam pendidikan agama Islam. Merujuk kepada arti majelis taklim itu sendiri bahwa majelis taklim adalah: 1. Pengajaran (agama Islam), menanamkan norma agama melalui kaji dan dakwah, 2. Pembacaan AlQur'an. ${ }^{23}$

Dari defenisi di atas dapat kita cerna bahwa majelis taklim secara umum mempunyai dua bentuk, jadi materi yang disajikanpun berbeda antara satu sama lain walaupun pada hakekatnya sama untuk memperdalam pemahaman tentang agama Islam.

\footnotetext{
${ }^{23}$ Tim Penyusun Kamus Pusat Bahasa, Op., Cit., hlm. 491.
} 
Majelis taklim dengan arti pengajaran agama Islam secara garis besar mempunyai tiga materi yaitu:

a. Akidah (Keimanan)

Iman berarti percaya. Pendidikan keimanan berarti proses kependidikan tentang berbagai aspek kepercayaan. ${ }^{24}$ Menurut rumusan para ulama Tauhid, iman berarti membenarkan dengan hati, mengingrarkan dengan lidah akan wujud dan keesaan Allah. Rumusan ini kemudian dilengkapi oleh para ulama Asy'ariyah menjadi "membenarkan dengan hati, mengingrarkan dengan lidah akan ajaran yang dibawa oleh Rasulullah SAW dari Allah". ${ }^{25}$

Pendidikan keimanan di dalam al-Qur'an merupakan proses pendidikan Islam yang menuntun Individu untuk merealisasikan ketakwaan di dalam jiwa. Pendidikan keimanan tersebut melingkupi segala kewajibannya yang tercakup dalam rukun iman yang enam, yaitu: ${ }^{26}$

1) Beriman kepada Allah

2) Beriman kepada para Malaikat

3) Beriman kepada Kitab-Kitab

4) Beriman kepada para Rasul

5) Beriman kepada Hari Akhir

6) Beriman kepada Qada dan Qadar Allah

Pendidikan rohani sebagai salah satu dimensi pendidikan Islam tidak hanya ditempuh melalui hubungan antara hamba dengan penciptanya secara langsung, tetapi juga melalui interaksi hamba dengan berbagai fenomena alam dan lapangan kehidupan, baik sosial maupun fisik. Dengan kata lain, pendidikan Islam memperhatikan pengembangan keimanan tidak hanya melalui perkara ghaib, fenomena rohaniah dan peribadahan semata. Kitab alam yang terbuka ini dengan segala fenomena alamnya serta berbagai ilmu dan praktik kehidupan dapat memperkokoh dan berkaitan dengan penanaman keimanan. Pendidkan keimanan bertujuan untuk memupuk dan mengembangkan dasar ketuhanan yang ada sejak lahir, memelihara manusia dari kemusyirikan dan menghindarkan diri dari pengaruh akal fikiran yang menyesatkan. ${ }^{27}$

\footnotetext{
${ }^{24}$ Zakiah Daradjat, Metodik Khusus Pengajaran Agama Islam, (Jakarta: Bumi Aksara, 1995), hlm. 63 .

${ }^{25}$ Ibid.,

${ }^{26}$ Mohammad Daud Ali, Pendidikan Agama Islam, (Jakarta: Rajawali Pers, 2001), hlm. 200-201.

${ }^{27}$ Masan Alfat, Aqidah Akhlak (Madrasah Tsanawiyah), (Semarang: Toha Putra, 1994), hlm. 5-6.
} 
b. Syariat (ibadah)

Dalam mendefenisikan ibadah Malik Fadjar dan Abdul Ghafir memberikan dua pengertian, yaitu: ${ }^{28}$

1) Ibadah dalam pengertian umum ialah semua amalan yang diizinkan oleh Tuhan dan yang ditetapkan secara terperinci mengenai keharusan mengerjakannya.

2) Ibadah dalam pengertian khusus ialah apa-apa yang telah ditetapkan Tuhan secara terperinci baik tingkat maupun kaifiyat(cara-caranya) yang tertentu: misalnya shalat, puasa, haji dan sebaagainya.

Jadi pendidikan ibadah dapat didefenisikan sebagai proses kependidikan tentang berbagai aspek amalan yang telah ditetapkan oleh Allah SWT. Amaliah (ibadah) tercakup di dalam 5 rukun Islam, yaitu: ${ }^{29}$

1) Syahadat yaitu kesaksian ataupun ikrar yang harus diucapkan oleh setiap muslim pada awal mula menyatakan keIslamanya.

2) Shalat yaitu sistem peribadatan yang terdiri dari beberapa perkataan dan perbuatan yang dimulai dengan takbir dan diakhiri dengan salam, menurut beberapa syarat dan rukun tertentu.

3) Zakat yaitu mensucikan dari nilai kotor (lebih) yang ada pada harta kekayaan (pemilikan), yang pada hakekatnya menjadi hak dari tenaga yang menghasilkannya.

4) Puasa yaitu menahan diri dari hal-hal yang membatalkan puasa mulai dari terbit fajar sampai terbenam matahari, dengan niat melaksanakan perintah Allah serta semata-mata mengharap ridhanya.

5) Haji yaitu menyengaja menjunjungi Ka'bah untuk melakukan beberapa amal ibadat, dengan syarat-syarat tertentu.

Ibadah adalah bukti keimanan kepada Allah dan tanda penyerahan diri kepada-Nya. Orang yang menjalankan ibadah sebagai jalan hidupnya dan bahagia dalam jiwanya, karena ia menyerahkan diri sepenuhnya kepada Allah.

Ibadah dapat membimbing dan merubah sikap dan sifat kecendrungan yang negatif bagi seseorang menjadi positif dan dapat meringankan segala sengsara dan duka hati dalam kehidupan dunia, serta menjadi penenang hati dan penentram jiwa ketika tertimpa musibah, karena isi (hakekat) ibadah itu adalah mengingat Allah yang maha pengasih lahi maha penyayang. ${ }^{30}$

\footnotetext{
${ }^{28}$ Ibid., hlm. 70.

${ }^{29}$ Ibid., hlm. 71.

${ }^{30}$ M. Ja'far, Beberapa Aspek Pendidikan Islam, (Surabaya: Al-Ikhlas, 1982), hlm. 46.
} 
Pendidikan ibadah merupakan kegiatan yang bertujuan mendorong yang diajar terampil memperbuat pekerjaan ibadah itu, baik dari segi kegiatan anggota badan, ataupun dari segi bacaan. Ringkasnya, anak didik yang diajar itu dapat melakukan ibadah dengan mudah karena memiliki pengetahuan tentang itu dan mendorong agar ia senang melakukan ibadah itu dengan baik, terutama ibadah wajib sehari-hari seperti shalat, bersuci, puasa, dan lain-lain. ${ }^{31}$ c. Akhlak

Kata akhlak berasal dari Bahasa Arab bentuk jamak dari "al-khuluq" yang berarti perangai, sikap, perilaku, watak, budi pekerti. ${ }^{32}$ Malik fajar mengutip pendapat Imam Ghazali dalam hal mengidentifikasikan akhlak, yaitu: ${ }^{33}$

Akhlak ialah suatu gejala kejiwaan yang sudah meresap dalam jiwa, yang dari padanya timbul perbuatan-perbuatan dengan mudah, tanpa mempertimbangkan pikiran terlebih dahulu.Apabila yang tibul dari padanya adalah perbuatan-perbuatan yang baik, terpuji menurut akal dan syara maka disebut akhlak yang baik.Sebaliknya, apabila yang timbul dari padanya adalah perbuatan yang jelek maka dinamakan akhlak yang buruk.

\section{Pengamalan Keagamaan Ibu Rumah Tangga}

Pengamalan keagamaan terdiri dari dua kata yaitu pengamalan dan keagamaan. Pengamalan berasal dari kata amal, artinya "segala sesuatu yang dikerjakan dengan maksud berbuat kebaikan". ${ }^{34}$ Keagamaan berasal dari kata agama yaitu ajaran, system yang mengatur tata keimanan (kepercayaan) dan peribadatan kepada tuhan yang mahakuasa serta tata kaidah yang berhubungan dengan pergaulan manusia serta lingkungannya.

Dari uraian di atas, apabila digabungkan pengertian pengamalan dan agama, maka pengamalan keagamaan adalah perbuatan yang dilakukan seorang hamba sebagai bentuk ikatan/kepatuhan kepada Allah SWT dalam rangka mendekatkan diri, dengan taat dan patuh melaksanakan perintah dan anjuran-Nya serta menjauhi segala larangan-Nya. Pengamalan keagamaan yang dimaksud di sini adalah melaksanakan ajaran agama dalam kehidupan sehari-hari, khususnya dalam aspek akidah, ibadah dan akhlak.

\footnotetext{
${ }^{31}$ Zakiah Daradjat. Op, Cit., hlm. 76.

${ }^{32}$ Mohammad Daud Ali. Op, Cit., hlm. 135.

${ }^{33}$ Malik Fadjar. Op, Cit., hlm. 99.

${ }^{34}$ W.J.S. Poerwadarminta. Kamus Umum Bahasa Indonesia (Jakarta: Balai Pustaka, 2006),
} hlm. 29. 
Ibu rumah tangga adalah "wanita yang mengatur penyelenggaraan berbagai macam pekerjaan rumah tangga, istri (ibu) yang hanya mengurusi berbagai macam pekerjaan dalam rumah tangga (tidak bekerja di kantor)". Yang dimaksud ibu rumah tangga di sini adalah wanita yang mengikuti pengajian majelis taklim.

Pengamalan keagamaan ibu rumah tangga disini adalah segala perintah Allah SWT, seperti melaksanakan shalat wajib, melaksanakan shalat sunnah, melaksanakan puasa, tidak menggunjing tetangga, tidak suka membicarakan aib orang lain, dan sebagainya.

\section{Penutup}

Majelis taklim adalah suatu wadah organisasi sebagai tempat perkumpulan orang banyak dalam rangka mengikuti pengajaran agama Islam. Dimana para jama'ahnya ada dari kalangan ibu-ibu dan juga bapak-bapak baik yang masih muda maupun yang sudah lanjut usia. Majelis taklim juga merupakan wahana para da'i atau ustadz untuk menyampaikan berbagai pengajaran agama Islam sesuai dengan kebutuhan para jama'ahnya.

Pengamalan keagamaan adalah perbuatan yang dilakukan seorang hamba sebagai bentuk ikatan/kepatuhan kepada Allah SWT dalam rangka mendekatkan diri, dengan taat dan patuh melaksanakan perintah dan anjuran-Nya serta menjauhi segala larangan-Nya. Pengamalan keagamaan yang dimaksud di sini adalah melaksanakan ajaran agama dalam kehidupan sehari-hari, khususnya dalam aspek akidah, ibadah dan akhlak. Pengamalan keagamaan ibu rumah adalah segala perintah Allah SWT, seperti melaksanakan shalat wajib, melaksanakan shalat sunnah, melaksanakan puasa, tidak menggunjing tetangga, tidak suka membicarakan aib orang lain, dan sebagainya.

\section{Referensi}

Ahmad Al-Hasyim, Mukhtarul Ahadis, Indonesia: Al-Haramain Jaya, 2005.

Dewan Redaksi, Ensiklopedi Islam Jilid III, Jakarta: Ikthiar Baru Van Hoeve, 2001.

Enung K Rukiati dan Fenti Hikmawati, Sejarah Pendidikan Islam di Indonesia Bandung: Pustaka Setia, 2006.

Hasbullah, Kapita Selekta Pendidikan Islam, Jakarta: PT Raja Grafindo Persada, 1996.

Helmawati, Pendidikan Nasional dan Optimalisasi Majelis Taklim: Peran Aktif Majelis Taklim Meningkatkan Mutu Pendidikan, Jakarta: Rineka Cipta, 2013. 
Kustini, Peningkatan Peran Serta Masyarakat Dalam Pendalaman Ajaran Agama Melalui Majelis Taklim, Jakarta: Puslitbang Kehidupan Keagamaan, 2007. M. Ja'far, Beberapa Aspek Pendidikan Islam, Surabaya: Al-lkhlas, 1982.

M. Ridlwan Nasir, Mencari Tipologi Format Pendidikan Ideal, Yogyakarta: Pustaka Pelajar, 2005.

Masan Alfat, Aqidah Akhlak (Madrasah Tsanawiyah), Semarang: Toha Putra, 1994.

Mohammad Daud Ali, Pendidikan Agama Islam, Jakarta: Rajawali Pers, 2001.

Muhaimin, Pengembangan Kurikulum Pendidikan Agama Islam di Sekolah, Madrasah, Dan Perguruan Tinggi, Jakarta: RajaGrafindo Persada, 2009.

Mukhtar, Desain Pembelajaran Pendidikan Agama Islam, Jakarta: Misaka Galiza, 2003.

Muzayyin Arifin, Kapita Selekta Pendidikan Islam, Jakarta: Bumi Aksara, 2003.

Muzayyin Arifin, Kapita Selekta Pendidikan Islam, Jakarta: PT Bumi Aksara, 2003.

Tim Penyusun Kamus Departemen Pendidikan dan Kebudayaan, Kamus Besar Bahasa Indonesia, Jakarta: Balai Pustaka, 2001.

W.J.S. Poerwadarminta. Kamus Umum Bahasa Indonesia, Jakarta: Balai Pustaka, 2006.

Zakiah Daradjat, Metodik Khusus Pengajaran Agama Islam, Jakarta: Bumi Aksara, 1995. 